\title{
Avaliação de praças na cidade de Quixadá-CE: um estudo sob a ótica da ergonomia do ambiente construído
}

\author{
Squares evaluation in Quixadá-CE city: a study under built \\ environment ergonomic focus
}

\author{
ANTONIO AURISEU NOGUEIRA PINHEIRO \\ Mestrando, UFC - PPGAU+D, auriseunogueira@gmail.com
}

ALANA ARAGÃO VASCONCELOS

Mestranda, UFC - PPGAU+D, alanaavasconcelos@gmail.com

ZILSA MARIA PINTO SANTIAGO

Doutora, UFC -PPGAU+D, zilsa@arquitetura.ufc.br

VILMA VILLAROUCO

Doutora em Engenharia, UFPE - PPGDESIGN/PPERGO, UFC -PPGAU+D, vvillarouco@gmail.com

\section{RESUMO}

Dada a relevância da praça enquanto espaço público de encontro, convivência e socialização, buscase, com este trabalho, realizar a avaliação de duas praças na cidade de Quixadá-CE. Este estudo faz parte da pesquisa de mestrado em andamento, que trabalha o espaço público e as questões de urbanidade em cidades de médio porte. Para este artigo o enfoque é a ergonomia do ambiente construído, e o estudo tem como base a Metodologia Ergonômica para o Ambiente Construído MEAC (VILLAROUCO, 2008). A metodologia é composta por cinco fases: análise global do ambiente; identificação da configuração ambiental; avaliação do ambiente em uso; percepção ambiental do usuário; e diagnóstico ergonômico do ambiente. Considerando tanto os aspectos físicos e ambientais, quanto comportamentais, o estudo contempla a avaliação da percepção dos usuários, bem como as suas relações com o espaço. O levantamento de dados ocorre nas duas praças e centra-se no método comparativo. Por fim, além de apontar as principais problemáticas das praças selecionadas, foram propostas recomendações para contribuir com possíveis soluções, ou ao menos, amenizar os problemas identificados.

PALAVRAS-CHAVE: Ambiente construído; Ergonomia; MEAC; Praça.

\section{ABSTRACT}

The relevance of the square as a public space for meeting, socializing and socializing, it seeks to conduct an evaluation of two squares in the city of Quixadá-CE. This study is part of the ongoing master's research, which works the public space and urbanity issues in medium-sized cities. For this 


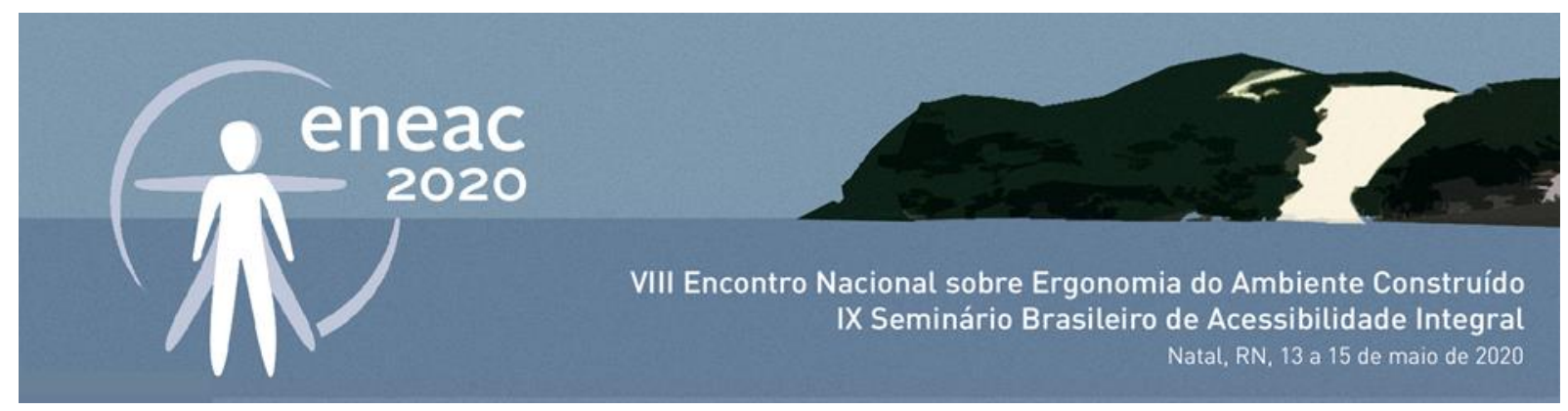

article, the focus is on ergonomics of the built environment and the study is based on the Ergonomics in Built Environment - MEAC (VILLAROUCO, 2008). The method is composed by five phases: global analysis of the environment, identification of the environmental configuration, assessment of the environment in use, environmental perception of the user and ergonomic diagnosis of the environment as well their relations with space. Data collection takes place in two squares and comparative method is used. Lastly, in addition to pointing out the main problems of the selected squares, recommendations were proposed to contribute to possible solutions, or at least, relieve the problems encountered.

KEYWORDS: Built environment; Ergonomic; MEAC; Square.

\section{INTRODUÇÃO}

A praça, além de um espaço público característico do meio urbano, é o lugar intencional do encontro, da permanência, dos acontecimentos, de práticas sociais, de manifestações da vida urbana e comunitária (LAMAS, 1993). Seja na escala da pequena cidade, seja em uma metrópole, a praça é um espaço potencialmente propício às relações de convivência e socialização.

Tendo como o objeto central a praça, o presente artigo busca abordar a temática da qualidade do espaço público em pequenas e médias cidades. Mesmo diante da intensidade dos processos de urbanização e metropolização, a maior parte do território brasileiro, segundo dados do IBGE, é composto por pequenas e médias cidades. Apresentando dados mais precisos, $94,18 \%$ dos municípios têm uma população inferior a cem mil habitantes, número significativo para que esses territórios mereçam visibilidade.

Como delimitação da área de estudo, foram analisadas praças da cidade de Quixadá. O município está situado na Região de planejamento do Sertão Central cearense, localizado a uma distância de $168 \mathrm{~km}$ de Fortaleza, capital do Estado. Atualmente possui uma população estimada de 87.728 habitantes. De maneira mais específica, tem-se como recorte espacial o Centro, bairro no qual atualmente existem cinco praças, dessas, para o desenvolvimento do estudo, foram escolhidas duas. Considerando a poligonal do bairro, essas duas praças estão localizadas na região mais central e correspondem também aquelas que demostram um maior fluxo de usuários, sendo assim, esses foram os parâmetros norteadores para estabelecimento dos critérios de seleção.

O estudo de praças constitui-se como elemento de relevância no contexto de avaliação da qualidade do espaço público, considerando que o nível de urbanidade pode propiciar a condição de atrair as pessoas para o convívio social e melhoria da qualidade de vida. Niemeyer (2015) menciona que a praça, espaço público por excelência carregada de simbolismo, marca a rotina de uma cidade comprometida com a urbanidade e com sua herança cultural.

Essa qualidade espacial abordada no estudo, tem como enfoque a ergonomia do ambiente construído. Mais especificadamente, foi aplicada a Metodologia Ergonômica para o Ambiente Construído - MEAC (VILLAROUCO, 2008). Com essa análise, busca-se a abordagem de aspectos físicos, cognitivos, e, sobretudo, busca o entendimento da percepção dos usuários dos espaços. 


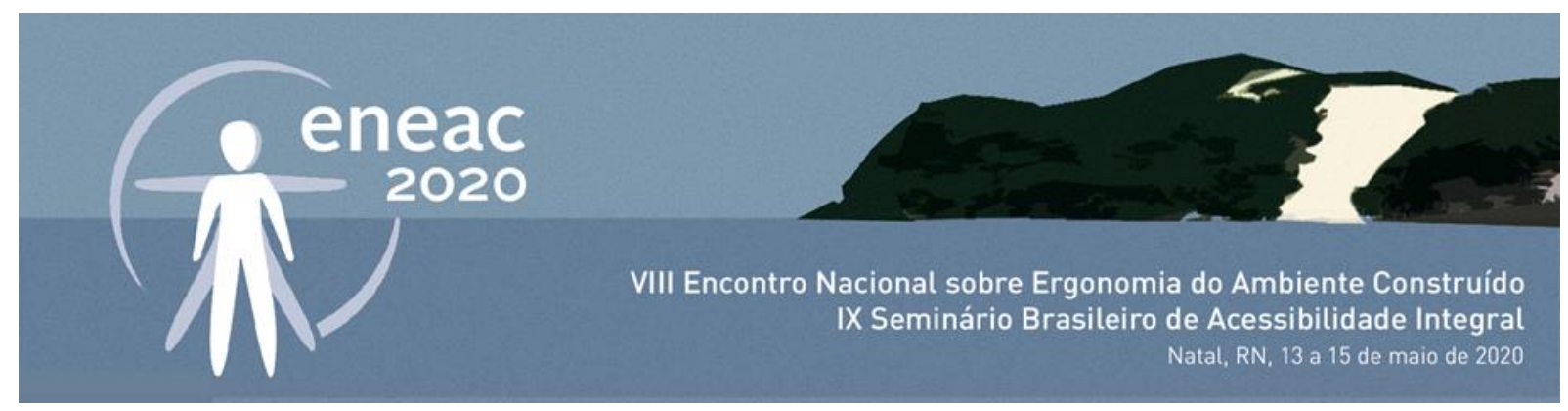

\section{METODOLOGIA}

A presente pesquisa caracteriza-se como uma pesquisa de campo do tipo exploratória-descritiva, e utiliza como base a Metodologia Ergonômica para o Ambiente Construído - MEAC (VILLAROUCO, 2008). A abordagem avalia o ambiente em uso, tendo como foco o desempenho das atividades exercidas pelos seus usuários.

A metodologia é composta por cinco fases: a primeira etapa é a Análise Global do Ambiente, fase de reconhecimento e levantamento de dados iniciais, em que foi aplicado o método walkthrough. A segunda etapa é a Identificação da Configuração Ambiental e consistiu no levantamento de dados de dimensionamento, iluminação, ventilação, ruído, layout, materiais de revestimento e condições de acessibilidade. A terceira fase é a Avaliação do Ambiente em Uso, na qual é observada a efetiva realização das atividades, sendo utilizados como instrumentos: o mapeamento comportamental, anotações de fluxos, além do uso da antropometria para análise de mobiliários. A quarta etapa é a Percepção Ambiental do Usuário, nessa fase foram identificadas quantitativamente as opiniões dos usuários das praças, na qual foram adotadas as ferramentas: entrevista estruturada e formulário. E a última fase é o Diagnóstico Ergonômico do Ambiente, que além de apontar os problemas e pontos fortes, são atribuídas sugestões de melhorias e soluções.

\section{RESULTADOS E DISCUSSÕES}

\subsection{Análise Global do Ambiente}

As praças escolhidas para o desenvolvimento da pesquisa estão situadas no Centro da cidade de Quixadá-CE, são elas: a Praça José de Barros, e a Praça Coronel Nanan, conforme a localização apresentada na figura 1. Para fins de apresentação deste trabalho, a Praça José de Barros foi denominada como Praça 1, enquanto a Praça Coronel Nanan foi denominada como Praça 2.

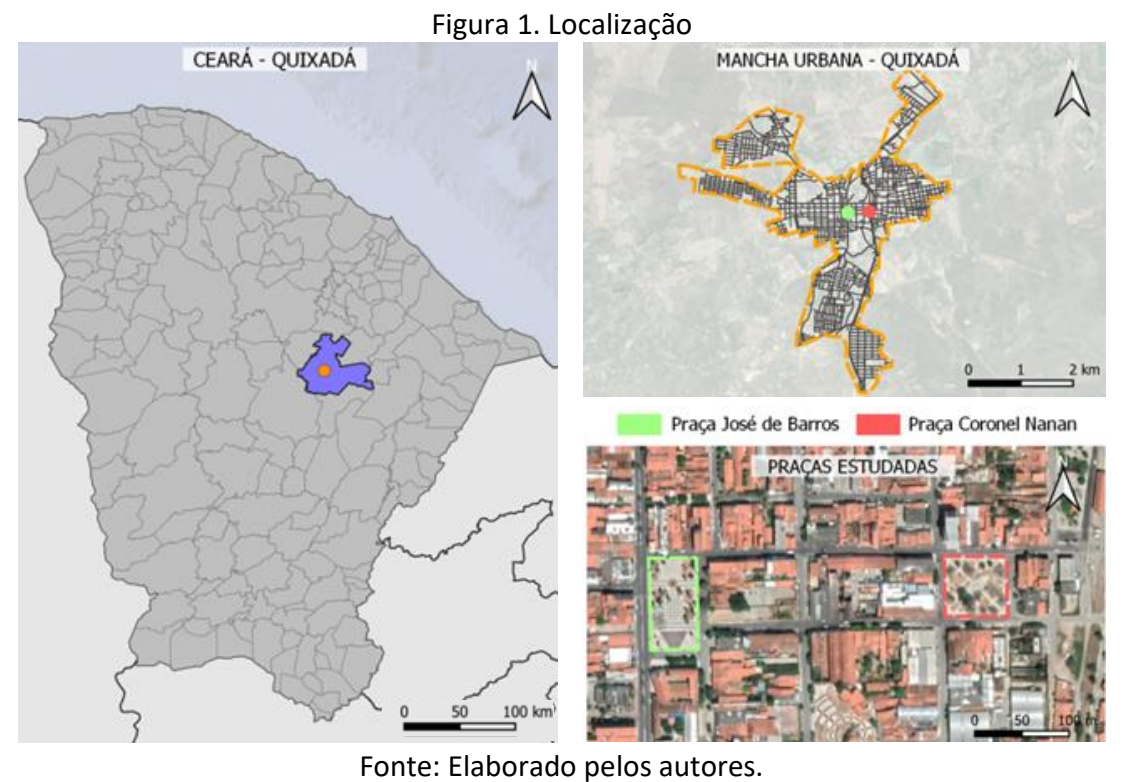

Fonte: Elaborado pelos autores. 


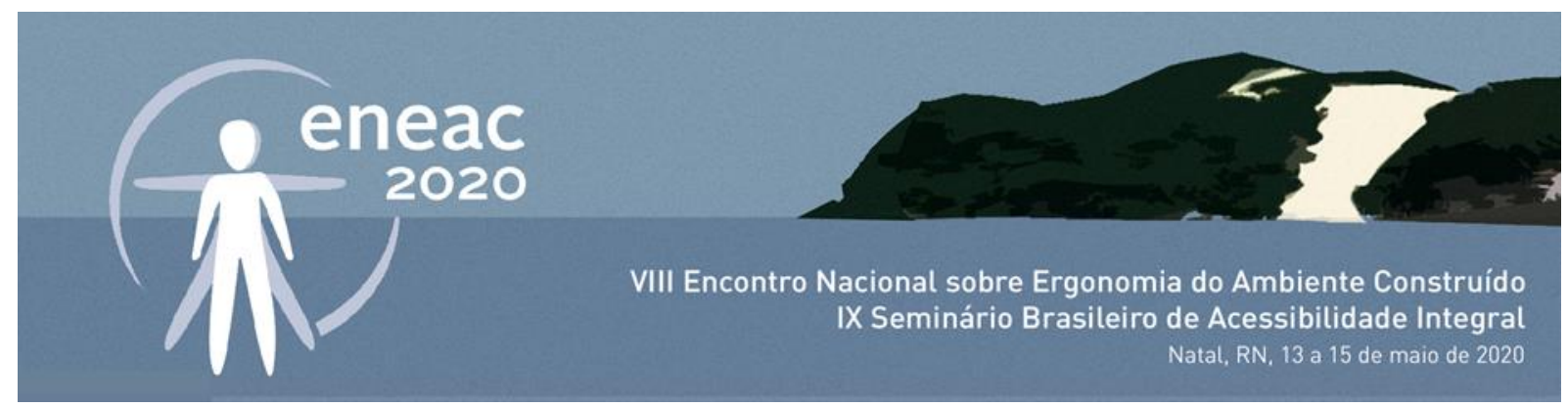

A Praça José de Barros (figura 2) foi construída na década de 1920 e é popularmente conhecida como Praça do Leão. Sendo uma das mais antigas da cidade, é tida por muitos como um ponto de referência e resgate de memórias. Hoje, além de ser um espaço de lazer e convivência, é também palco de alguns dos principais eventos e shows da cidade.

A Praça Coronel Nanan (figura 3) também possui representatividade na história da cidade e teve sua construção na década de 1930. Possui várias denominações, tais como: Praça dos Crentes, Praça da Biblioteca e Praça do Sindicado. No ano de 2017 foi instalado o letreiro "Eu amo Quixadá", tornandoa um espaço simbólico e procurado por moradores e turistas para fotografias.

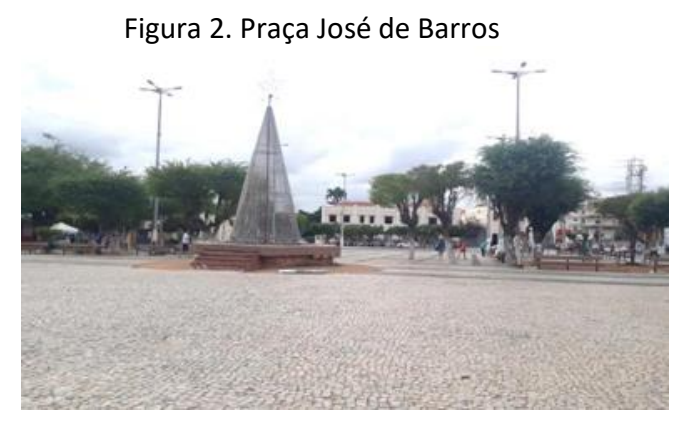

Fonte: Arquivo pesquisa.

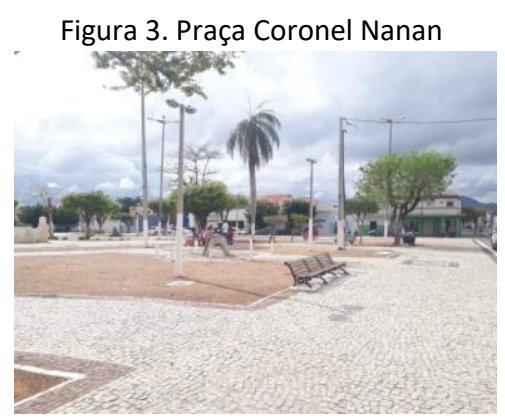

Fonte: Arquivo pesquisa.

A partir do método Walkthrough foram realizadas visitas nas duas praças, objetivando assim, uma percepção mais abrangente acerca do objeto. Pinto e Dorneles (2018) citam que o Walkthrough deve ser um dos primeiros instrumentos de pesquisa a ser realizado, por identificar de maneira mais rápida e prática os principais problemas de um ambiente construído.

Na Praça 1, a primeira impressão obtida é de um espaço amplo. Essa amplitude proporciona a sensação de vazio, devido à existência de poucos equipamentos e mobiliários. Já na Praça 2, mesmo possuindo poucos equipamentos, não é tão evidente essa percepção de ociosidade, possivelmente devido à existência de um desenho mais orgânico, com incidência de muitos passeios e canteiros. Em ambas as praças a arborização aparenta ser insuficiente, tanto do ponto de vista estético, como funcional, isso em virtude da necessidade de áreas sombreadas. Além disso, a ausência da grama nos canteiros reforça ainda mais a carência do verde para trazer mais vitalidade ao espaço. Outro problema recorrente, percebido em ambas as praças nessa primeira visita, é a falta de acessibilidade.

\subsection{Avaliação da configuração ambiental}

\subsubsection{Layout e Mobiliário}

A Praça José de Barros possui uma área total de $5.594 \mathrm{~m}^{2}$, sendo que $695 \mathrm{~m}^{2}$ é de área permeável e o restante é revestida com pedra portuguesa. As áreas permeáveis estão sem cobertura vegetal de grama. Os equipamentos existentes são: um palco elevado, um quiosque, uma banca de jornal, e uma estátua em concreto de um leão, em referência à denominação do espaço.

A praça Coronel Nanan possui uma área de $4.473 \mathrm{~m}^{2}$. Desse total, $1.893 \mathrm{~m}^{2}$ é de solo exposto em terra batida, e o percentual restante é pavimentado com pedra portuguesa. Comparando as taxas de 


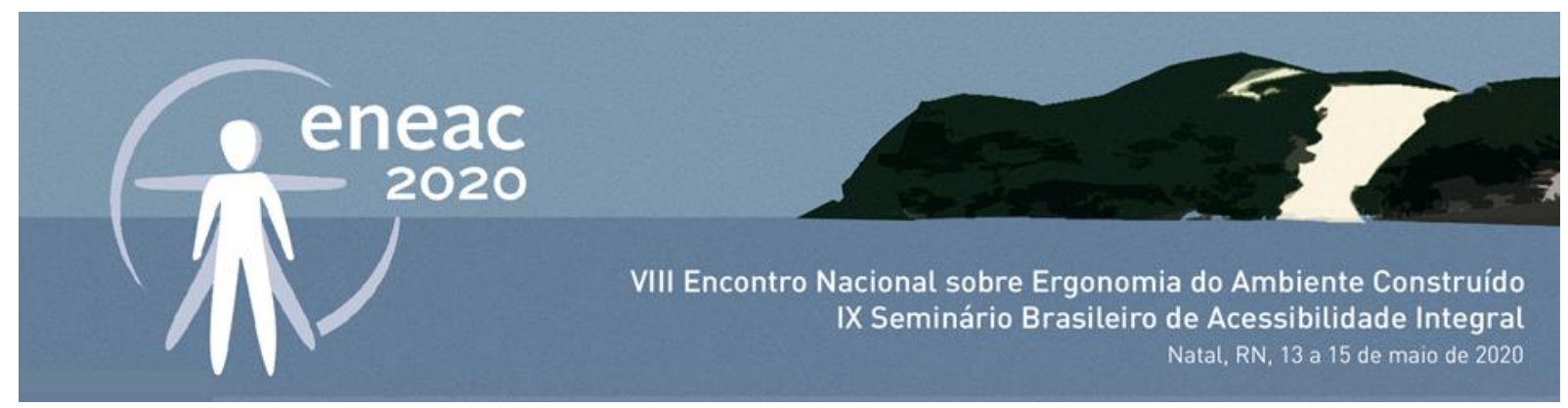

permeabilidade das duas praças, obtêm-se índices bem discrepantes. Na primeira, apenas $12,42 \%$ de áreas permeáveis, contra $42,32 \%$ da segunda. O programa de necessidades da Praça 2 é composto por um palco elevado, um monumento em mármore e um letreiro: "Eu amo Quixadá". As figuras 4 e 5 contêm as plantas baixas das praças, bem como as indicações dos equipamentos e mobiliários. Esses desenhos foram elaborados com base em imagens de satélite do Google Maps e complementados com levantamentos realizados in loco.
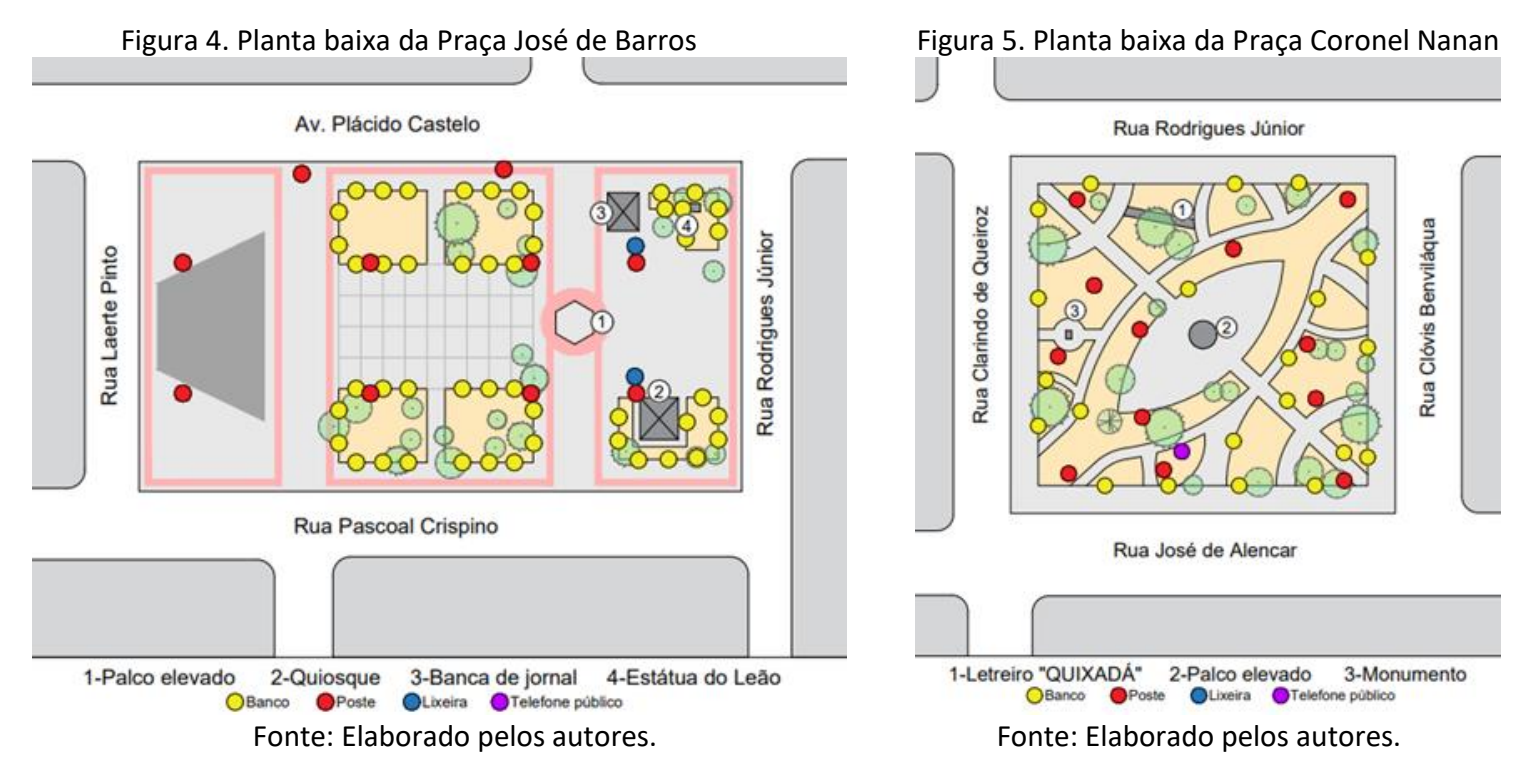

São poucos os tipos de mobiliários existentes nas duas praças, ficando evidente a necessidade de uma diversidade de equipamentos que contribuam para uma maior atratividade desses ambientes. Além de não haver uma diversificação de tipologias, alguns dos mobiliários têm um quantitativo insuficiente para a demanda do local, como é o caso das lixeiras, em que na Praça 1 existem apenas duas lixeiras, e na Praça 2 não foi identificada nenhuma.

Comparando-se o layout das duas praças, verifica-se de imediato que a concepção do projeto de cada uma atende a objetivos distintos: na Praça 1, a existência de um palco elevado requer um espaço mais vazio para realização de eventos, como já citado, é o local onde acontecem os principais eventos e shows da cidade. Nos períodos em que não estão se realizando esses eventos, o espaço amplo, ocioso, provoca sensação de vazio. Enquanto na Praça 2, o layout mais orgânico, simétrico, com vários espaços caminháveis e mais arborização, nos parece um local mais aconchegante e propício ao encontro e convívio de pessoas.

\subsubsection{Acessibilidade}

A acessibilidade é um aspecto de relevância notória para a garantia de um acesso livre e adequado ao espaço público, podendo ser definida como a possibilidade e condição de alcance, percepção e entendimento para utilização, com segurança e autonomia, de espaços, mobiliários, equipamentos urbanos, edificações, transportes, informação e comunicação por pessoa com deficiência ou mobilidade reduzida (NBR 9050/2015). 


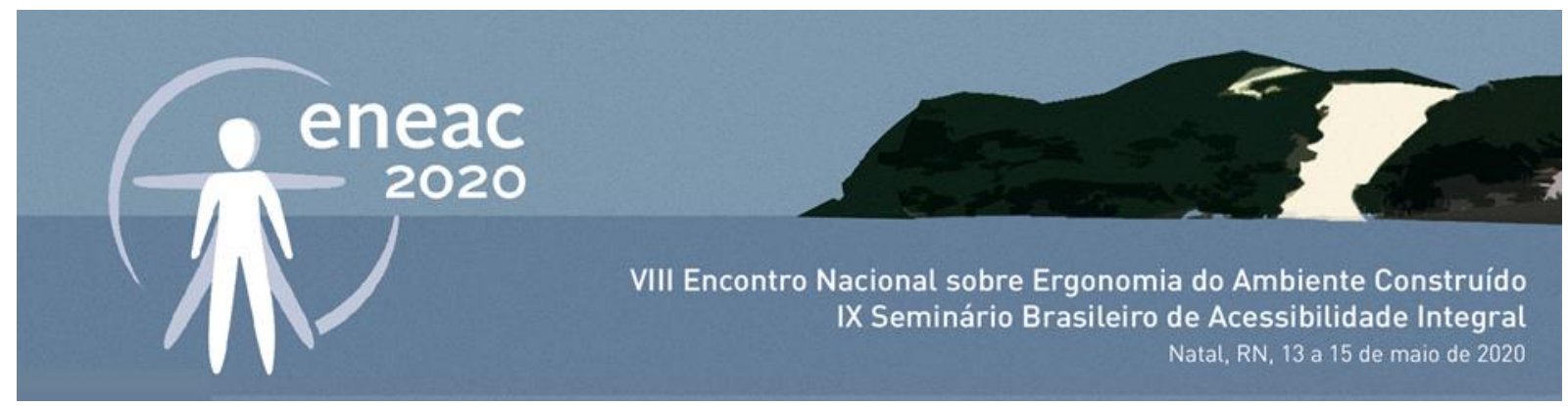

Para a avaliação da acessibilidade nas duas praças, foi utilizado como parâmetro o modelo de checklist, proposto por Santiago et al (2016). A ficha é direcionada à avaliação de praças e contempla o estudo da acessibilidade, analisando as categorias: passeios, travessias e guias rebaixadas, estacionamentos na via pública junto às praças, vegetação e piso tátil de alerta e direcional. Para adequação ao presente estudo foram realizados pequenos ajustes ao modelo. Os dados coletados através da observação in loco foram averiguados conformes às especificações da NBR 9050/2015 e do Guia de Acessibilidade: Espaço Público e Edificações do Governo do Estado do Ceará (2009). Os resultados obtidos estão representados no Quadro 1.

Quadro 1. Checklist de acessibilidade

\begin{tabular}{|c|c|c|}
\hline Critérios & Praça 1 & Praça 2 \\
\hline \multicolumn{3}{|l|}{ Quanto ao passeio: } \\
\hline Existência de revestimento de piso & Adequado & Adequado \\
\hline Tipo de pavimentação dos passeios; & Inadequado & Inadequado \\
\hline Estado de conservação; & Inadequado & Inadequado \\
\hline Existência de pelo menos uma rota acessível; & Inadequado & Inadequado \\
\hline Largura mínima em passagens de circulação. & Adequado & Inadequado \\
\hline Total & $\begin{array}{l}\text { Adequado: } 40 \% \\
\text { Inadequado: } 60 \%\end{array}$ & $\begin{array}{l}\text { Adequado: } 20 \% \\
\text { Inadequado: } 80 \%\end{array}$ \\
\hline \multicolumn{3}{|l|}{ Quanto às travessias e guias rebaixadas: } \\
\hline Largura mínima de $1,20 \mathrm{~m} ;$ & Inadequado & Inadequado \\
\hline Inclinação máxima de 8,33\%; & Inadequado & Inadequado \\
\hline Abas laterais da rampa com largura mínima de $50 \mathrm{~cm}$ & Inadequado & Inadequado \\
\hline Abas laterais com inclinação recomendada de $10 \%$ & Inadequado & Inadequado \\
\hline Desnível entre o término da rampa e o leito carroçável; & Inadequado & Adequado \\
\hline Localização da guia rebaixada junto à faixa de pedestre; & Inadequado & Inadequado \\
\hline Rampas alinhadas entre si dos lados opostos da via & Inadequado & Inadequado \\
\hline Corte no canteiro central; & Inadequado & Não se aplica \\
\hline Piso tátil de alerta; & Inadequado & Inadequado \\
\hline Piso tátil direcional conectando a rampa de travessia & Inadequado & Inadequado \\
\hline Total & $\begin{array}{c}\text { Adequado: } 0 \% \\
\text { Inadequado: } 100 \%\end{array}$ & $\begin{array}{l}\text { Adequado: } 11 \% \\
\text { Inadequado: } 89 \%\end{array}$ \\
\hline \multicolumn{3}{|l|}{ Sobre estacionamentos na via pública junto às praças } \\
\hline Vagas reservadas para pessoas com deficiência (PcD); & Inadequado & Inadequado \\
\hline Vagas reservadas para idosos; & Inadequado & Inadequado \\
\hline Nas vagas reservadas para PcD existência de espaço lateral de $1,20 \mathrm{~m}$ & Inadequado & Inadequado \\
\hline $\begin{array}{l}\text { Sinalização visual horizontal e vertical para os dois tipos de vagas } \\
\text { reservadas }\end{array}$ & Inadequado & Inadequado \\
\hline Localização das vagas reservadas próximas aos polos de atração. & Inadequado & Inadequado \\
\hline Total & $\begin{array}{l}\text { Adequado: } 0 \% \\
\text { Inadequado: } 100 \%\end{array}$ & $\begin{array}{c}\text { Adequado: } 0 \% \\
\text { Inadequado: } 100 \%\end{array}$ \\
\hline \multicolumn{3}{|l|}{ Sobre a vegetação: } \\
\hline Existência de raízes que danificam o passeio; & Adequado & Adequado \\
\hline Existência de espécies espinhosas; & Inadequado & Adequado \\
\hline Existência de espécies venenosas; & Adequado & Adequado \\
\hline Espécies que liberam frutos ou resina sobre o piso; & Adequado & Adequado \\
\hline Existência de galhos podados deixando livre 2,10m. & Adequado & Adequado \\
\hline Total & $\begin{array}{l}\text { Adequado: } 80 \% \\
\text { Inadequado: } 20 \%\end{array}$ & $\begin{array}{l}\text { Adequado: } 100 \% \\
\text { Inadequado: } 0 \%\end{array}$ \\
\hline \multicolumn{3}{|l|}{$\begin{array}{l}\text { Sobre a sinalização de alerta: } \\
\text { Em torno dos obstáculos suspensos com altura entre } 0.60 \mathrm{~m} \text { e } 2.10\end{array}$} \\
\hline Em torno dos obstáculos suspensos com altura entre $0,60 \mathrm{~m}$ e 2,10 & Inadequado & Inadequado \\
\hline
\end{tabular}




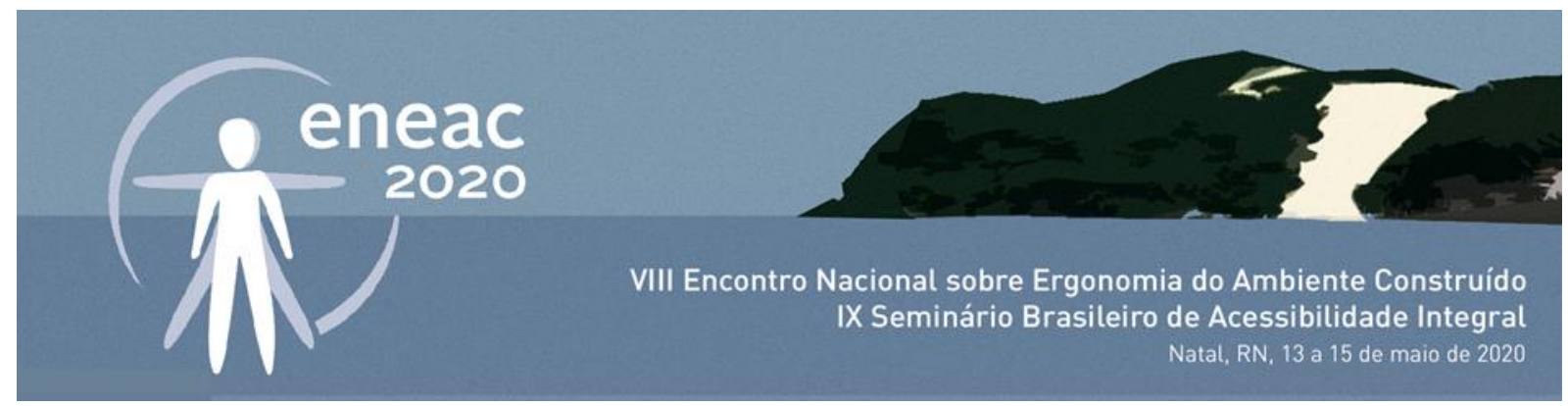

\begin{tabular}{l|c|c} 
Nos rebaixamentos de calçadas; & Inadequado & Inadequado \\
\hline No início e término de escadas; & Inadequado & Inadequado \\
\hline No início e término de rampas; & Inadequado & Inadequado \\
\hline Junto a desníveis e paradas de ônibus. & Inadequado & Inadequado \\
\hline Sobre a Sinalização direcional: & & \\
\hline Em áreas de circulação na ausência de guia de balizamento; & Inadequado & Inadequado \\
\hline Em espaços amplos; & Inadequado & Inadequado \\
\hline De forma transversal às guias rebaixadas; & Inadequado & Inadequado \\
\hline Na divisa da calçada com o lote, quando não houver muro. & Inadequado & Inadequado \\
\hline Total & $\begin{array}{c}\text { Adequado: } 0 \% \\
\text { Inadequado: } 100 \%\end{array}$ & $\begin{array}{c}\text { Adequado: } 0 \% \\
\text { Inadequado: } 100 \%\end{array}$ \\
\hline
\end{tabular}

Fonte: Modelo de SANTIAGO et al (2016) com dados levantados pelos autores.

De modo geral, as praças apresentaram um desempenho insatisfatório na maioria das categorias analisadas. Quanto aos passeios, que são em pedra portuguesa, existe uma má aplicação do piso, de modo que a irregularidade das superfícies pode comprometer a locomoção de cadeirantes ou pessoas com mobilidade reduzida. Além disso, não existe nenhuma rota acessível, seja através de piso tátil ou guia de balizamento.

$\mathrm{Na}$ Praça 1, a quantidade de rampas é suficiente, no entanto, nenhumas delas segue os parâmetros prescritos pelas normas. Já na Praça 2, além de possuir rampas em apenas dois pontos da praça, as existentes também não seguem as recomendações das legislações. A inclinação, que deveria ser de $8,33 \%$, na Praça José de Barros chega a ser de até $25 \%$ (figura 6) e atinge os $28 \%$ na Praça Coronel Nanan. Nenhuma das abas laterais das rampas, quando existentes, atingiu o perfil de dimensionamento e inclinação. Além disso, destacam-se outros pontos observados: inexistência de piso tátil de alerta e direcional, mobiliários inadequados (telefone público alocado em área sem pavimentação além de não haver nenhum aparelho acessível, figura 7), existência de áreas elevadas sem a presença de rampa (figura 8), dentre outros problemas.

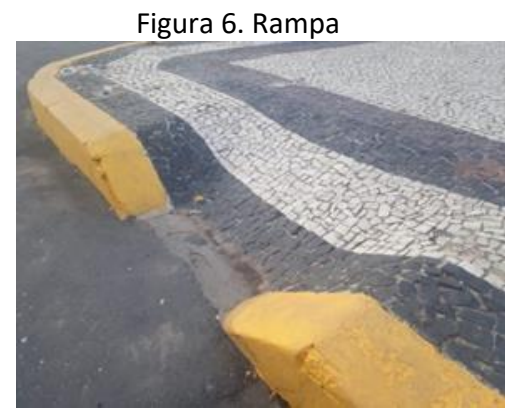

Fonte: Arquivo pesquisa.
Figura 7. Telefone Público

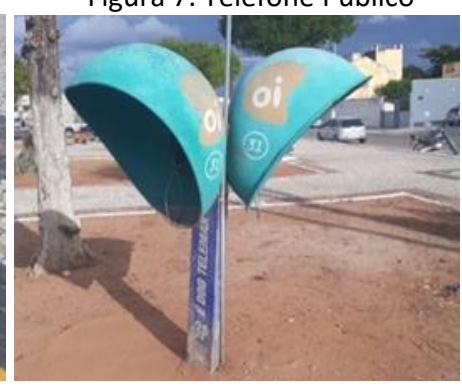

Fonte: Arquivo pesquisa.
Figura 8. Palco elevado

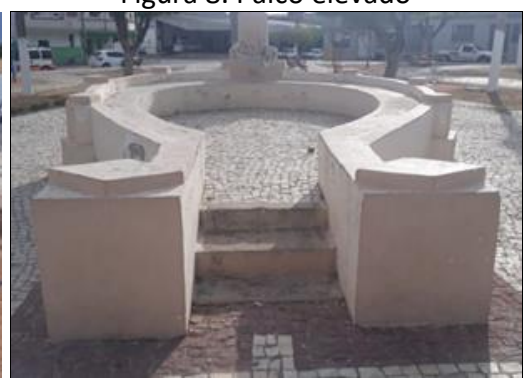

Fonte: Arquivo pesquisa.

\subsubsection{Avaliação do conforto ambiental}

Para avaliação do conforto lumínico foi utilizado o aplicativo Luxímetro. A NHO-11 é a norma indicada na NR17 (norma de ergonomia) para avaliação dos parâmetros de iluminação, entretanto, não foi utilizada nesse estudo, por tratar apenas dos níveis de iluminamento em ambientes internos de trabalho. Com isso, os resultados obtidos foram comparados à NBR 9050 de 2015, na qual estabelece que toda rota acessível deve ser provida de iluminação natural ou artificial, com nível mínimo de 


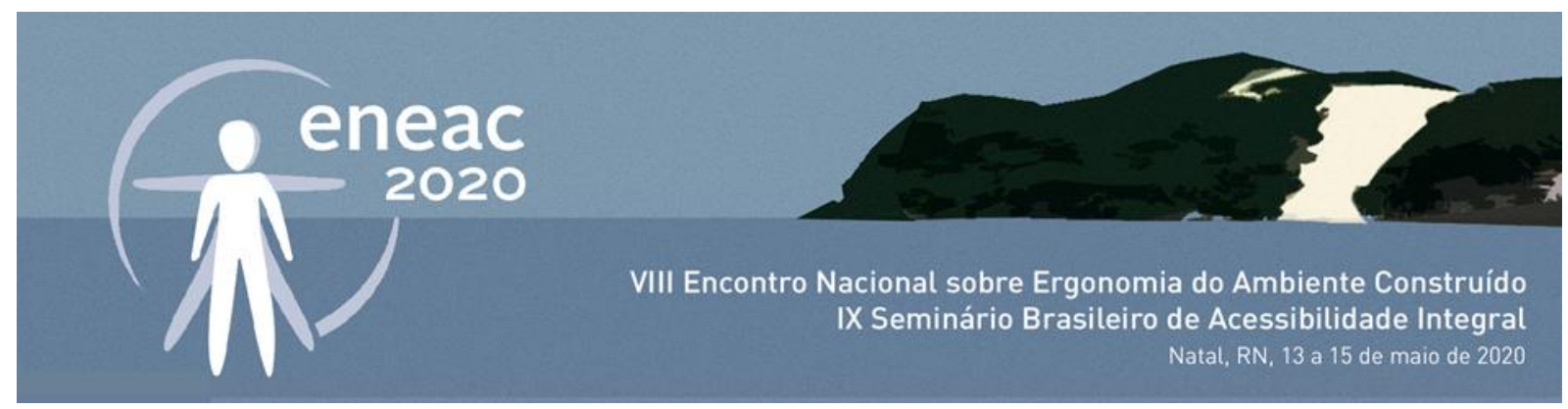

iluminância de 150 lux medidos a 1,00 m do chão. Foram definidos cinco pontos de coleta de dados em cada uma das praças. A localização desses pontos está especificada na figura 9 e os respectivos valores descritos na tabela 1 . As medições foram realizadas nos turnos da manhã, tarde e noite.

Figura 9. Pontos para análise do conforto lumínico.

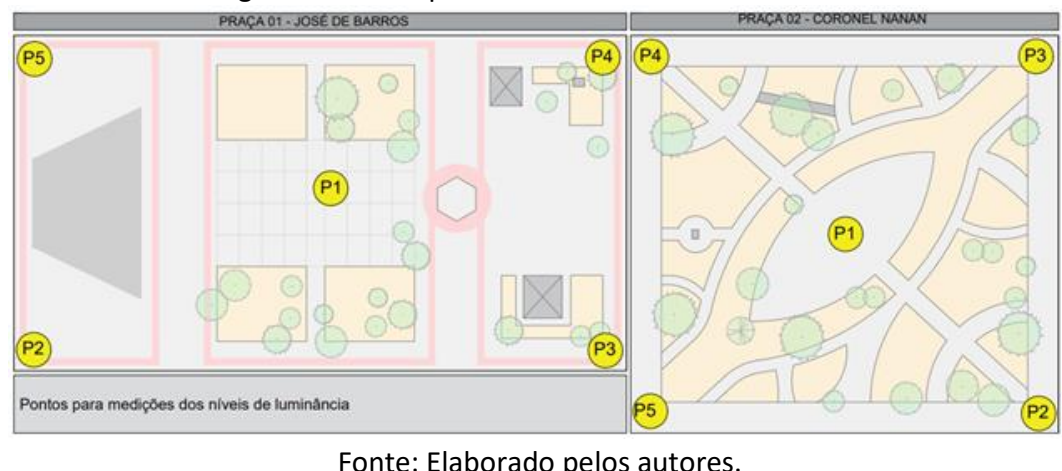

Tabela 1. Conforto ambiental

\begin{tabular}{|c|c|c|c|c|c|c|c|c|}
\hline & & \multicolumn{5}{|c|}{ Iluminação } & Acústi & Temneratura \\
\hline \multicolumn{2}{|c|}{ Norma } & \multicolumn{5}{|c|}{ NBR 9050} & NBR 10152 & NR 17 \\
\hline \multicolumn{2}{|c|}{ Valor referência } & \multicolumn{5}{|c|}{150 (lux) } & 60 dia - 55 noite $(\mathrm{dB})$ & $20-23\left({ }^{\circ} \mathrm{C}\right)$ \\
\hline \multicolumn{2}{|c|}{ Ponto de medição } & P1 & P2 & P3 & P4 & P5 & Central & Central \\
\hline \multirow{3}{*}{$\begin{array}{c}\text { Praça } \\
1\end{array}$} & $8: 00$ & 23.700 & 11.760 & 11.568 & 31.400 & 24.200 & 60 & 26 \\
\hline & $16: 00$ & 618 & 895 & 425 & 790 & 441 & 58 & 28 \\
\hline & 19:00 & 11 & 16 & 10 & 25 & 29 & 58 & 25 \\
\hline \multirow{3}{*}{$\begin{array}{c}\text { Praça } \\
2\end{array}$} & $8: 00$ & 35.000 & 34.440 & 42.530 & 24.750 & 34.440 & 62 & 26 \\
\hline & $16: 00$ & 449 & 1.140 & 1137 & 385 & 463 & 54 & 29 \\
\hline & 19:00 & 25 & 16 & 67 & 18 & 55 & 60 & 25 \\
\hline
\end{tabular}

Fonte: Elaborado pelos autores.

Todos os valores de lux coletados no período da manhã e tarde estão acima do indicado pela NBR 9050 para rotas acessíveis, fato que não acontece no turno da noite, quando foram observados índices muito abaixo do valor de referência de 150 lux. De modo geral, a Praça 2 apresentou um resultado melhor entre as duas.

$\mathrm{Na}$ avaliação do conforto acústico das praças, foi utilizando o aplicativo Sound Meter para medições dos níveis de decibéis. Teve-se como parâmetro os intervalos para o nível de ruído indicados pela NBR 10.151/2000 (Acústica - Avaliação do ruído em áreas habitadas, visando o conforto da comunidade Procedimento). Pelo fato de não haver uma variação considerável do nível de decibéis entre pontos distintos de uma mesma praça, foram analisadas as medições do ruído em um ponto central em cada um dos turnos.

Estabelecendo uma comparação entre os dados levantados e os valores prescritos pela norma, verifica-se que o turno da tarde foi o que apresentou o melhor desempenho, com os valores estando abaixo do recomendado. Já no período noturno, em ambas as praças foram obtidos níveis de decibéis acima dos desejáveis. 


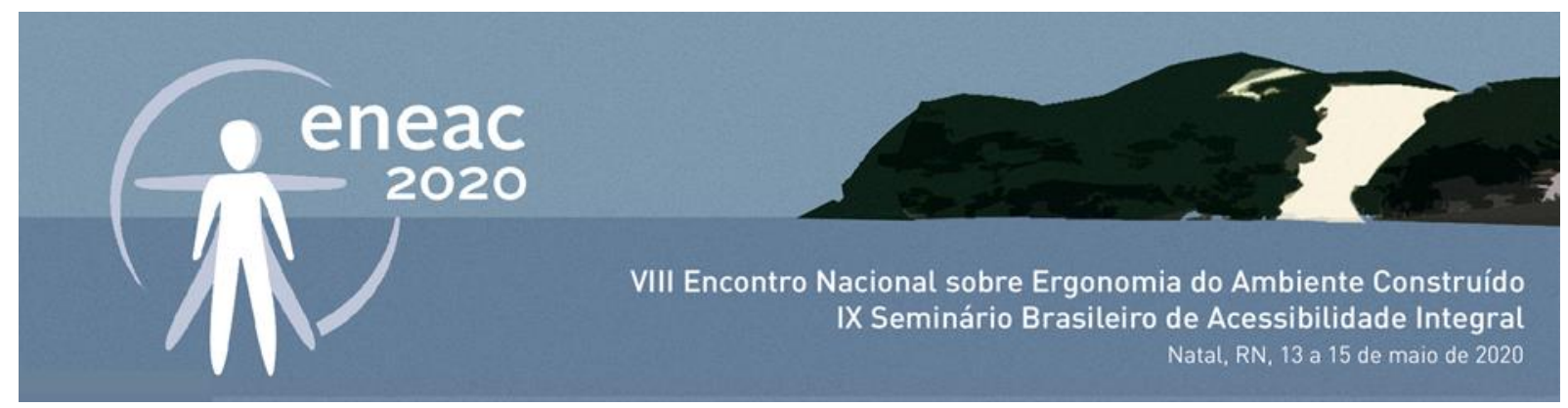

A análise da temperatura, assim como as demais medições, ocorreu em três horários distintos e foi realizada através do aplicativo Thermometer. A NR 17 trata de parâmetros de ambientes de trabalho e recomenda um índice de temperatura ideal entre $20^{\circ} \mathrm{C}$ e $23^{\circ} \mathrm{C}$. Entretanto, é necessário ponderar que o objeto de estudo trata de praças localizadas no Nordeste brasileiro, sendo conveniente considerar que uma praça nessa região não tenha $23^{\circ} \mathrm{C}$. Nesta direção, considera-se o trabalho de Freitas (2008), quando afirma que:

\begin{abstract}
"Um indivíduo em um clima temperado ou frio pode sentir-se confortável entre 14 e $18^{\circ} \mathrm{C}$. Enquanto isso, um habitante de um clima quente e úmido, como em Recife - PE, só vai sentir a mesma sensação de bem-estar em temperaturas próximas a $25^{\circ} \mathrm{C}$, para desenvolver suas atividades sem maiores esforços de adequação ambiental "(FREITAS, 2008, p.47).
\end{abstract}

\title{
3.3 Avaliação do ambiente em uso
}

A avaliação do ambiente em uso centrou-se na observação dos usuários desempenhando as atividades, bem como os principais fluxos realizados. A técnica para anotação dos dados foi o mapeamento comportamental. Pinheiro, Elali e Fernandes (2008) definem esse instrumento como um documento empírico correspondente à representação gráfica das localizações e comportamentos das pessoas no espaço, possibilitando assim, uma análise crítica dessas atividades desempenhadas.

As observações ocorreram nos três turnos distintos, visto que os usos do espaço apresentam uma maleabilidade a depender do horário do dia. O levantamento desses dados para a elaboração dos mapeamentos comportamentais ocorreu às $8 \mathrm{~h} 00,16 \mathrm{~h} 00$ e $19 \mathrm{~h} 00$, sendo que cada sessão de observação durava cerca de 40 minutos em cada praça.

Foram classificados como critério de análise: a faixa etária, por classificação mediante aparência de idade (criança, jovem, adulto ou idoso), a posição (sentado ou em pé), a atividade que estava sendo desempenhada pelo usuário e os principais fluxos das pessoas. As figuras 10, 11 e 12 apresentam esses mapeamentos comportamentais.

Figura 10. Mapeamento comportamental - Manhã

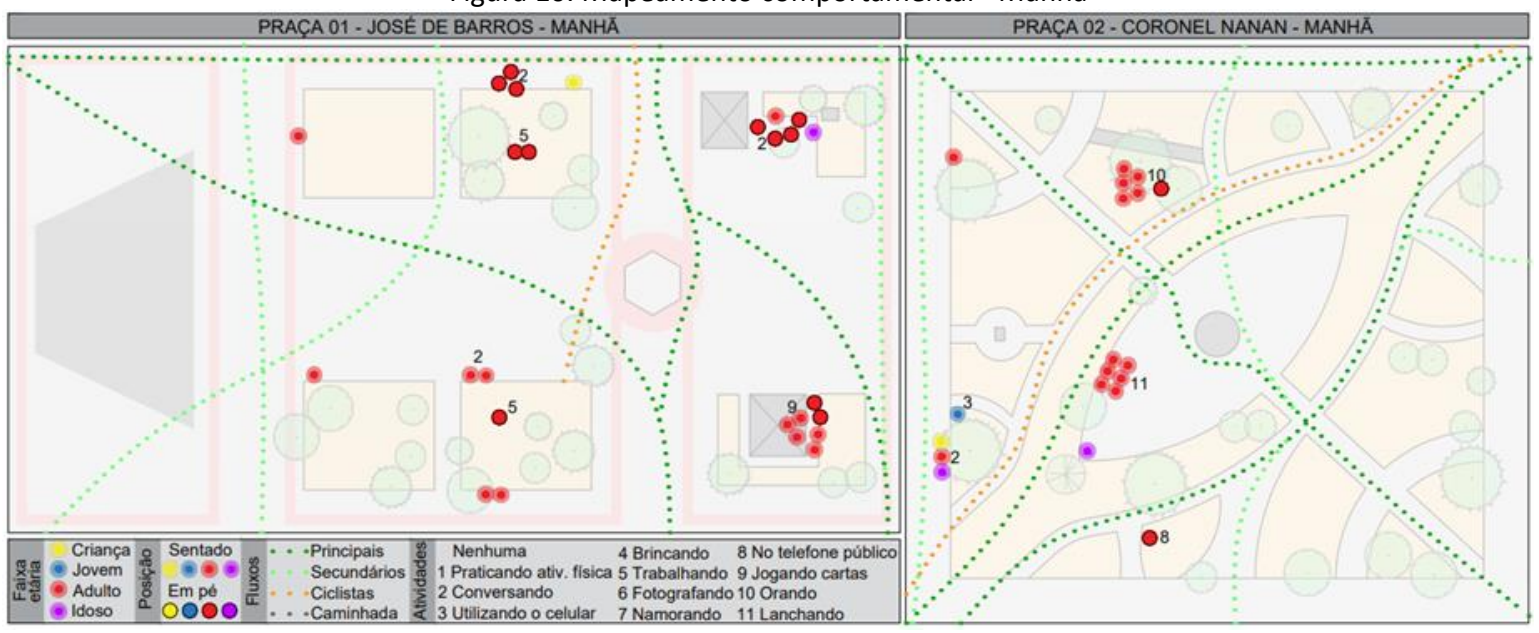

Fonte: Elaborado pelos autores. 


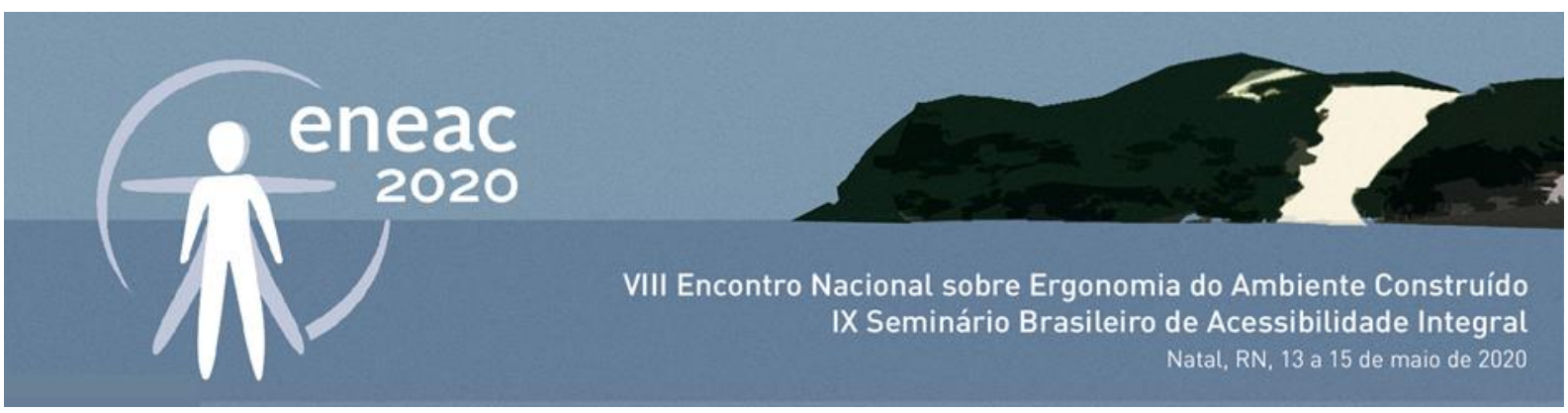

Figura 11. Mapeamento comportamental - Tarde

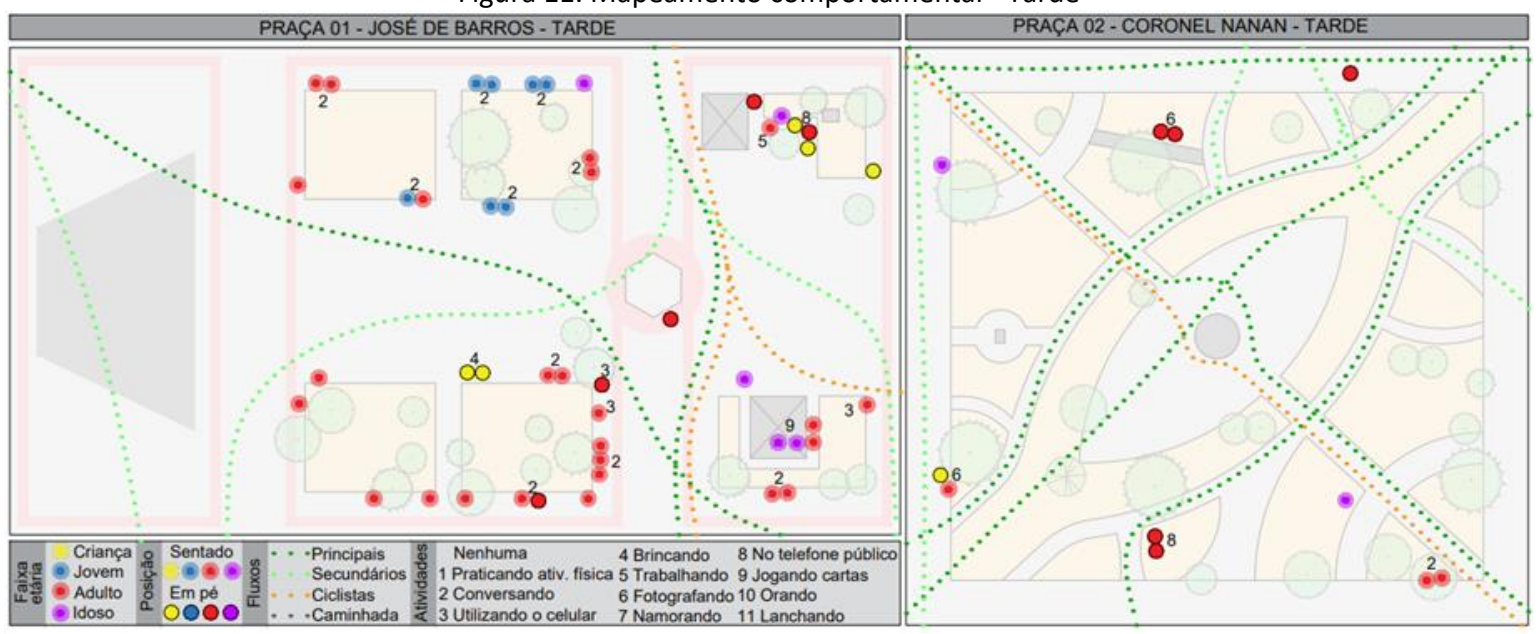

Fonte: Elaborado pelos autores.

Figura 12. Mapeamento comportamental - Noite

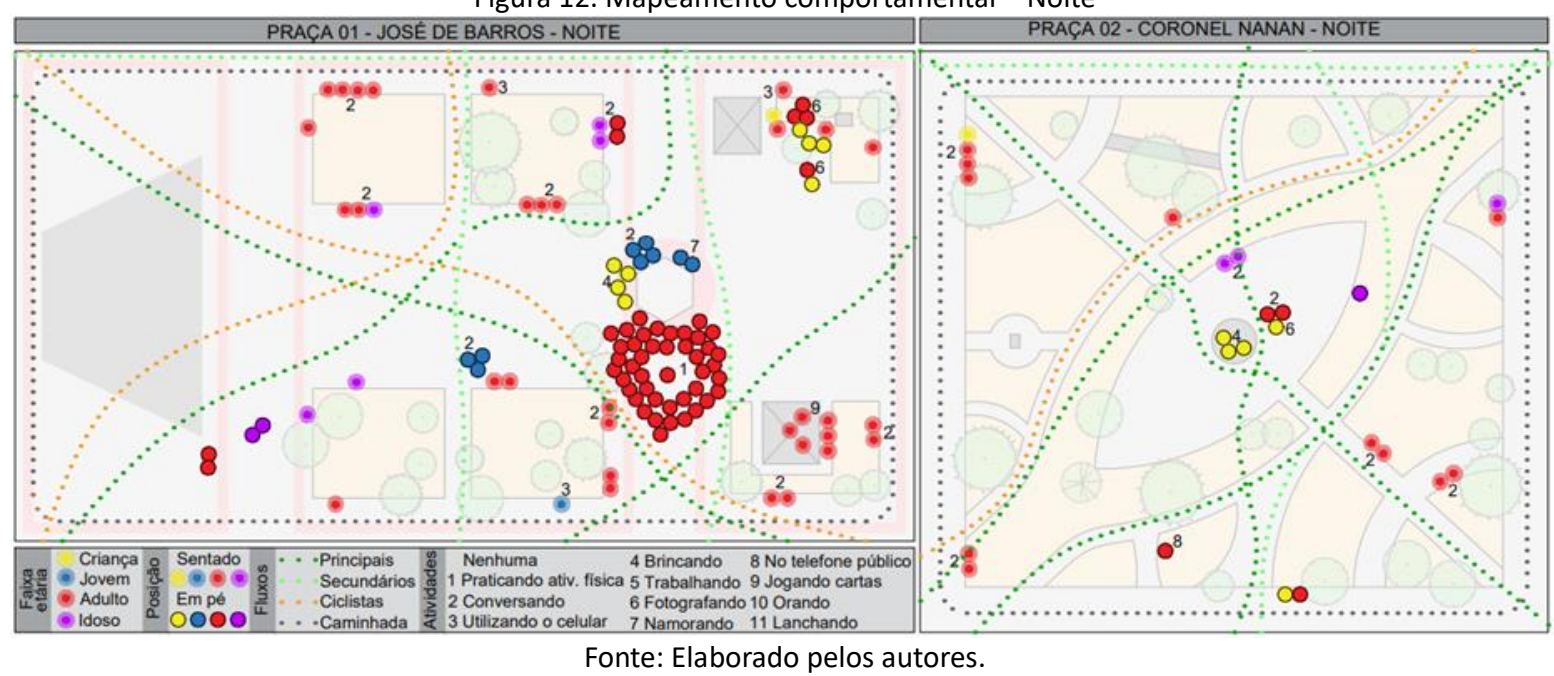

Estabelecendo uma comparação entre os turnos analisados, verifica-se que em ambas as praças o período noturno é o mais utilizado pelos usuários. Percebe-se também a predominância de adultos em relação às outras faixas etárias, sobretudo no turno da manhã.

A Praça 1 apresentou uma maior quantidade de usuários em todos os horários. Dentre as atividades mais recorrentes observadas nesta praça, destacam-se: pessoas conversando, jogando cartas, utilizando o celular e praticando atividade física. Segundo relato dos usuários, duas vezes por semana um grupo de pessoas se reúne na praça para a prática de atividades físicas. No dia da observação, o agrupamento era composto por cerca de 50 membros, essa aglomeração pode ser observada nas figuras 12 (planta) e 13 (fotografia).

Na Praça 2 observa-se uma menor variação quanto à faixa etária de usuários, ressaltando que praticamente não foram identificados jovens na praça. As atividades mais recorrentes foram: pessoas conversando, fotografando e utilizando o telefone público. Percebe-se que o telefone público é um mobiliário muito utilizado, visto que nos três turnos distintos havia pessoas utilizando-o. Ainda em 


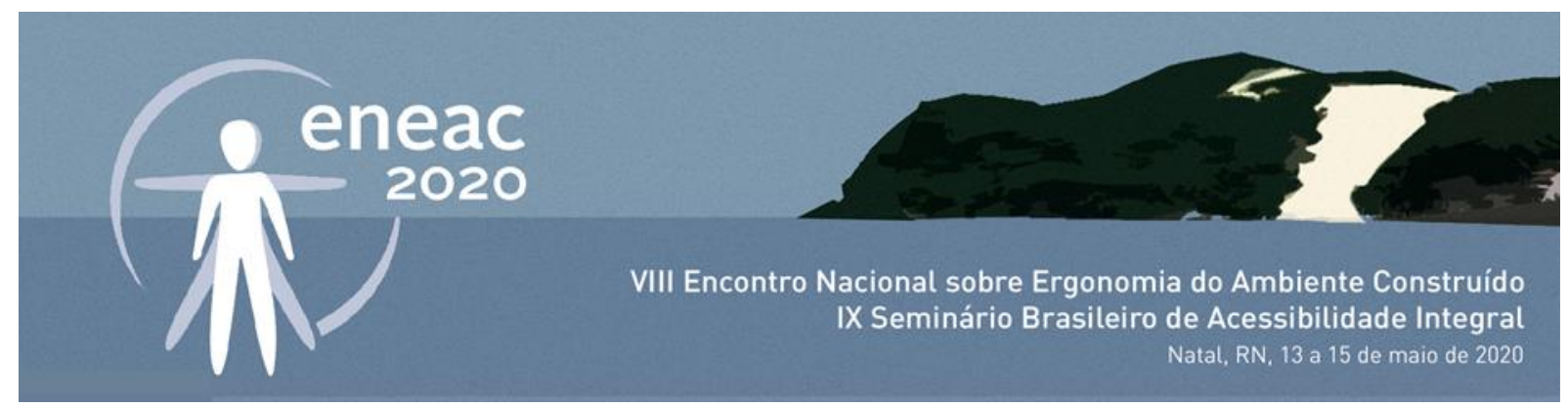

relação ao quesito mobiliário, percebe-se a carência de uma maior diversidade, como é demostrado na figura 14: uma criança brincando, fazendo escalada no palco elevado da Praça Coronel Nanan, dada a ausência de um playground.

Figura 13. Prática de ativ. física

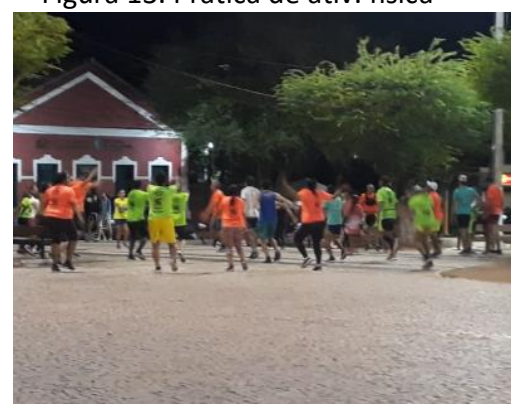

Fonte: Arquivo pesquisa.
Figura 14. Criança brincando

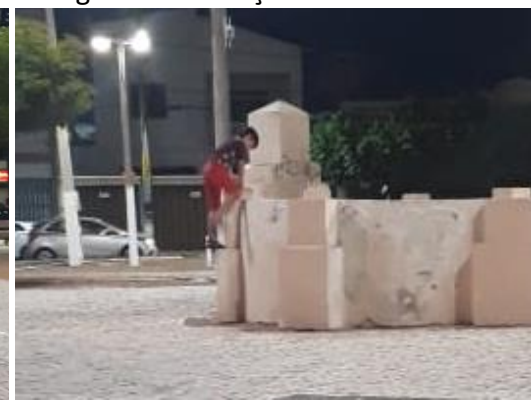

Fonte: Arquivo pesquisa.
Figura 15. Pessoas caminhando

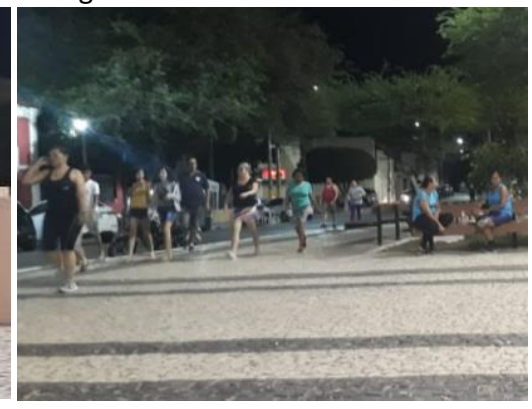

Fonte: Arquivo pesquisa.

Pelo próprio desenho dos espaços, a Praça 1 apresenta grandes áreas de circulação através de espaços amplos. Já na Praça 2 existem muitos percursos, porém, com dimensões mais reduzidas. Dada essas informações e analisando os fluxos anotados nos mapas comportamentais, verifica-se que mesmo não possuindo caminhos delimitados, a Praça 1 apresenta um sistema de fluxo mais lógico, sem tantas variações. Já na Praça 2, devido haver muitos passeios, os usuários desempenham uma maior variedade de percursos.

Em ambas as praças foram observados deslocamentos por parte de ciclistas. Outra questão relevante, analisada através das anotações de fluxo, foi o uso de ambas as praças para a prática de caminhada no período noturno (Figura 15). Sendo que, inversamente a quantidade de usuários, a Praça 2 foi mais utilizada para caminhada que a praça 1. Na Praça José de Barros havia 28 pessoas caminhando, enquanto na Praça Coronel Nanan havia 47, isso em horário noturno.

Ainda na etapa de avaliação do ambiente em uso, foram analisadas as dimensões dos bancos de ambas as praças. A finalidade foi verificar se estes estavam adequados sob o ponto de vista da ergonomia. O banco foi o mobiliário escolhido para análise, por ser o tipo mais recorrente nos espaços e também por ter uma maior influência em relação ao conforto proporcionado. Em cada uma das praças existe apenas um tipo de banco, esses modelos estão representados nas figuras 16, 17 e 18.

Os dois modelos foram analisados tendo por referência as dimensões adequadas de bancos proposta por Panero e Zelnik (2008). Em relação à altura do assento, a dimensão adequada é entre 40,6 a 43,2 $\mathrm{cm}$, desse modo, o banco da Praça 1 atingiu o perfil desejado, enquanto o banco da Praça 2 apresentou um valor muito inferior. Quanto ao encosto, o ideal é entre 45,7 a 61,0 cm, nesse caso, apenas o banco da Praça 2 apresentou a dimensão correta. Em relação à profundidade do assento, nenhum dos bancos se enquadram na medida adequada, que é entre 39,4 a 40,6 cm. A angulação sugerida de $105^{\circ}$ fica mais próxima de ser atingida no banco da Praça 1 , enquanto no outro apresenta um valor consideravelmente inadequado. Em síntese, os dois bancos apresentam muitas dimensões diferentes das almejadas, sendo que o banco da Praça 2 ainda demostrou um desempenho pior.

Cabe aqui o esclarecimento que não foi objetivo do trabalho realizar o levantamento antropométrico dos usuários das praças com fins de verificação da adequação dos bancos, mesmo considerando que 


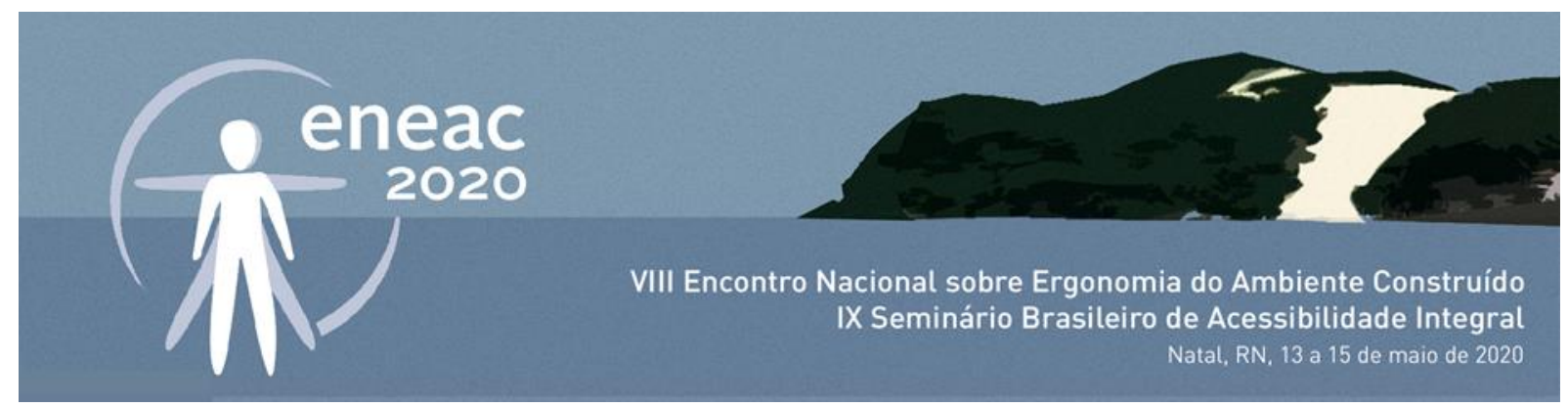

tal obtenção de medidas estabelecesse perfis diferenciados apenas para adultos e crianças, sem diferenciação para idosos. Primeiramente, considera-se que só há um tipo de banco em cada praça, não havendo mobiliário específico para o público infantil, tornando desnecessária a tomada de medidas da população de crianças, no contexto da presente análise.

Particularizando para as medidas de adultos, considera-se aqui a recomendação da literatura especializada, de que não se deve fazer levantamentos antropométricos muito específicos para populações particularizadas, ademais, no caso de tratar-se de espaços públicos e abertos, com grande diversidade de usuários.

Definiu-se assim usar as medidas trazidas por Panero e Zelnik (2008).

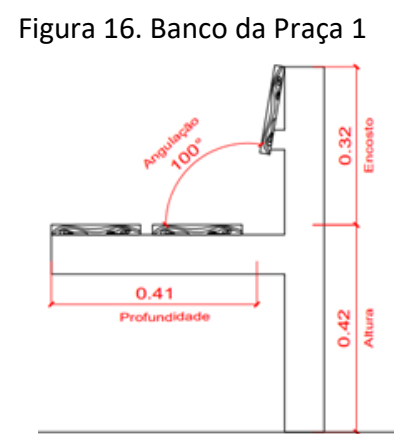

Fonte: Elaborado pelos autores.

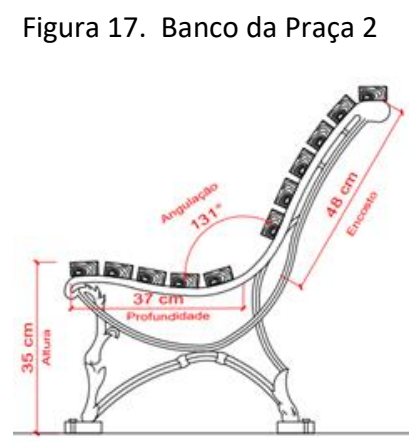

Fonte: Elaborado pelos autores.

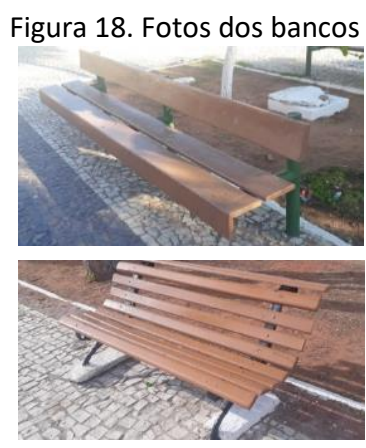

Fonte: Arquivo pesquisa.

\subsection{Percepção do ambiente}

Foram utilizadas duas ferramentas para identificar a opinião dos usuários, sendo que ambos os instrumentos foram aplicados para 40 pessoas nas praças: 20 usuários da Praça José de Barros e 20 da Praça Coronel Nanan. A primeira ferramenta de percepção escolhida foi uma entrevista estruturada. Gerhard e Silveira (2009) citam que a entrevista estruturada segue um roteiro previamente estabelecido através de perguntas predeterminadas. O objetivo é obter diferentes respostas à mesma pergunta, possibilitando que sejam comparadas. A utilização dessa ferramenta aplicada em MEAC pode ser encontrada no trabalho de Paiva e Villarouco (2008).

A primeira pergunta realizada foi em relação à frequência de uso da praça. Na Praça 1, a maioria dos entrevistados respondeu que dificilmente frequentam o espaço ( 9 pessoas), enquanto um número menor de usuários frequenta todos os dias ou ao menos três vezes por semana (6 pessoas), os demais frequentam com uma periodicidade mediana. Já na Praça 2, os usuários demostraram um uso mais frequente do espaço, sendo que 10, dos 20 entrevistados, vão todos os dias à praça.

Na segunda pergunta os usuários foram interrogados em relação ao motivo pelo qual frequentavam o espaço. Na Praça 1 as repostas mais recorrentes foram: conversar, tirar o estresse, praticar atividade física e lazer. Na Praça 2, os usuários responderam com maior frequência: conversar, namorar, tirar o estresse e caminhar. Comparando os dois resultados, não se percebem muitas diferenças de uso.

$\mathrm{Na}$ terceira pergunta foi questionado qual era o elemento mais atrativo da praça. Na Praça José de Barros, a localização foi o fator mais citado, seguido do valor patrimonial e com menor frequência foram mencionados: amplitude do espaço, aconchego, eventos, tranquilidade e o canto das aves. 


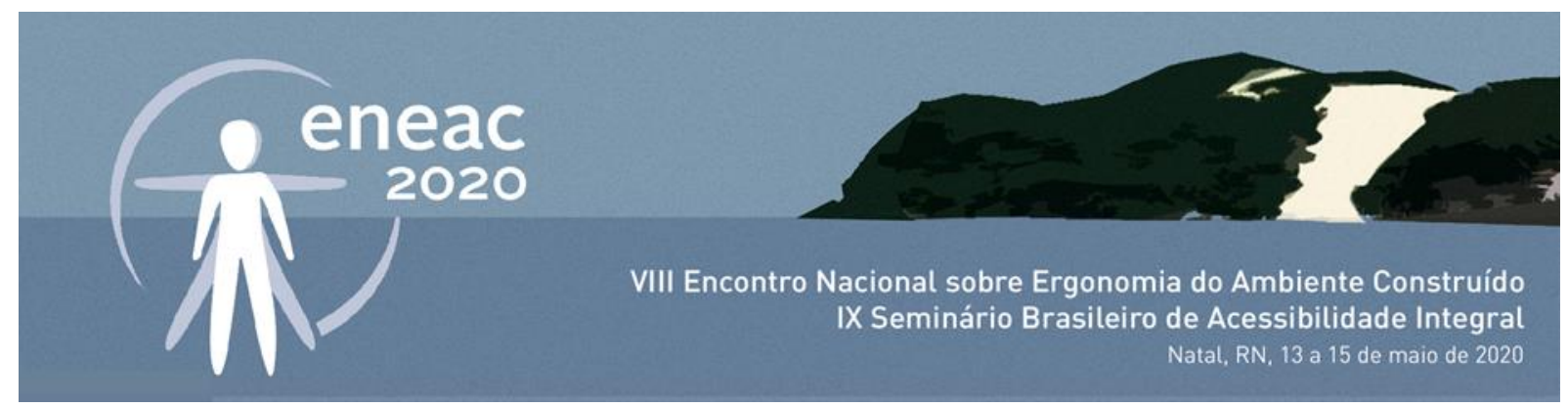

Destaca-se também que um número considerável de pessoas (6) disse não achar nenhum elemento atrativo. Na praça 2, o aspecto da localização também foi mencionado como o mais atrativo, seguido da tranquilidade e paisagem circundante, com menor frequência responderam: letreiro, árvores, bancos, iluminação, amplitude e Wi-Fi.

Na quarta pergunta foi interrogado se havia algum elemento na praça que não era agradável aos usuários. Na Praça 1, os aspectos mais citados foram: falta de mobiliário, falta de limpeza, sensação de insegurança, barulho, falta de vegetação, uso inadequado (brinquedos infantis privados em alguns dias da semana) e falta de local para lanches. Na Praça 2, os itens mais mencionados foram: falta de vegetação, falta de manutenção e falta de mobiliários. Em síntese, foram identificados mais problemas pelos usuários na Praça 1 que na 2.

A segunda ferramenta aplicada teve por objetivo identificar quantitativamente as opiniões dos usuários das praças. Através de um formulário, os entrevistados opinavam o grau de satisfação em relação a alguns aspectos, classificando-os como: péssimo, ruim, regular, bom ou ótimo. Esse modelo de categorização foi embasado no trabalho de Cabral et al (2012) em que foi aplicada a MEAC na avaliação de calçadas públicas. Gerhard e Silveira (2009) definem o formulário como uma coleção de questões que são formuladas e anotadas por um entrevistador, numa situação face a face com o entrevistado. 0 gráfico 1 apresenta os resultados obtidos.

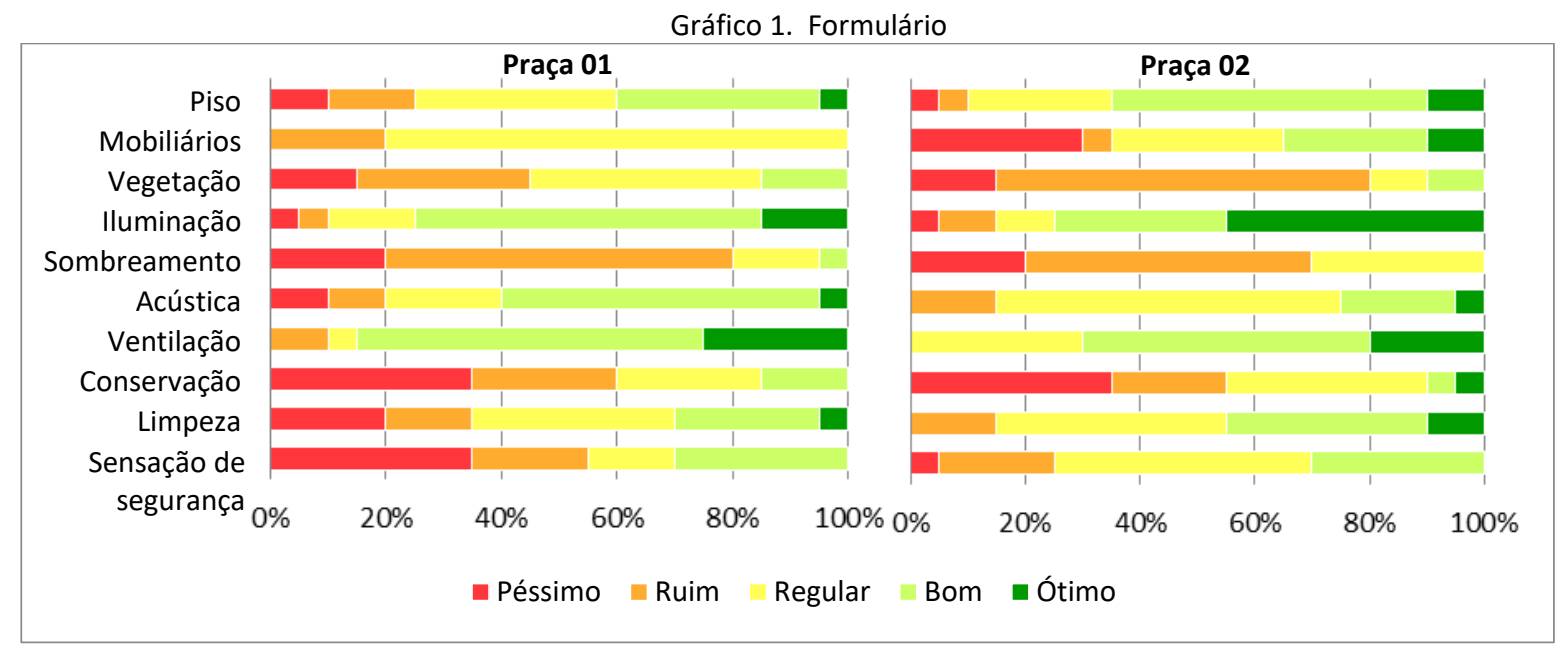

Fonte: Elaborado pelos autores.

Os aspectos que obtiveram uma melhor classificação na Praça 1 foram: Iluminação, acústica e ventilação, enquanto na Praça 2 foram: piso, iluminação, ventilação e limpeza. Em relação aos aspectos mais críticos, na Praça 1 destacam-se: mobiliários, vegetação, sombreamento, conservação, limpeza e sensação de segurança. Já na Praça 2: mobiliários, vegetação, sombreamento, acústica e conservação. Com isso, analisando um panorama geral do resultado do formulário, a Praça 1 apresentou mais problemáticas na percepção dos usuários. 


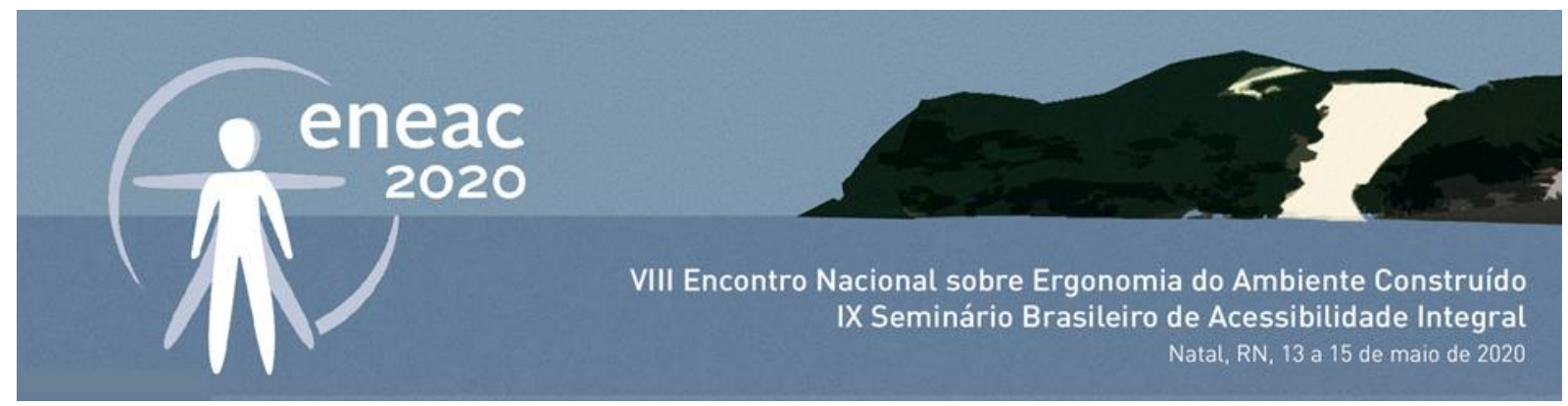

\subsection{Diagnóstico e recomendações}

Diante dos resultados obtidos nas fases anteriores da MEAC, foram diagnosticadas as principais problemáticas das praças analisadas e também os pontos positivos, bem como realizada a proposição de recomendações visando solucionar ou amenizar esses problemas. 0 quadro 1 expõe esses dados.

Quadro 1 - Diagnóstico e recomendações

\begin{tabular}{|c|c|c|}
\hline & Diagnóstico & Recomendações \\
\hline \multirow{15}{*}{$\begin{array}{c}\text { Gerais } \\
\text { (Praça } 1 \text { e } \\
\text { Praça 2) }\end{array}$} & Falta de diversificação de equipamentos & $\begin{array}{l}\text { Implantação de novos mobiliários ou equipamentos. Ex: } \\
\text { academia, playground, mesa de jogos, etc. }\end{array}$ \\
\hline & Vegetação insuficiente & $\begin{array}{l}\text { Plantação de árvores nativas com copas que permitam } \\
\text { sombreamento, arbustos e forrações. }\end{array}$ \\
\hline & Falta de lixeiras & Implantação de lixeiras com coleta seletiva \\
\hline & Piso com áreas irregulares & Substituição ou regularização do piso existente \\
\hline & Inexistência de rotas acessíveis & Implantação de sinalização tátil ou guias de balizamento \\
\hline & Rampas com inclinações inadequadas & $\begin{array}{l}\text { Adequação da inclinação da rampa, bem como o correto } \\
\text { dimensionamento das abas laterais }\end{array}$ \\
\hline & Rampas com revestimento escorregadio & Substituição do revestimento \\
\hline & $\begin{array}{l}\text { Ausência de sinalização tátil de alerta e } \\
\text { direcional }\end{array}$ & $\begin{array}{l}\text { Implantação de um sistema de sinalização tátil (de alerta e } \\
\text { direcional) }\end{array}$ \\
\hline & $\begin{array}{l}\text { Ausência de vagas para pessoa com } \\
\text { deficiência e idosos }\end{array}$ & $\begin{array}{l}\text { Destinação de vagas reservadas para pessoa com deficiência } \\
\text { e idosos }\end{array}$ \\
\hline & $\begin{array}{l}\text { Existência de áreas elevadas com acesso } \\
\text { exclusivo por degraus }\end{array}$ & Implantação de rampas de acesso \\
\hline & Índice elevado de decibéis & $\begin{array}{l}\text { Implantação de vegetações contribuindo para a absorção de } \\
\text { ruídos }\end{array}$ \\
\hline & Temperatura elevada & $\begin{array}{l}\text { Implantação de mais espécies vegetais e áreas sombreadas } \\
\text { (pergolados) para amenizar a incidência solar }\end{array}$ \\
\hline & $\begin{array}{l}\text { Bancos com dimensionamento } \\
\text { inadequado }\end{array}$ & $\begin{array}{l}\text { Substituição dos bancos para modelos com } \\
\text { dimensionamento correto }\end{array}$ \\
\hline & Falta de manutenção & Periodicidade no processo de manutenção das praças \\
\hline & Falta de áreas sombreadas & $\begin{array}{l}\text { Implantação pergolados, caramanchões, quiosques e mais } \\
\text { espécies vegetais }\end{array}$ \\
\hline \multirow{3}{*}{ Praça 1} & Existência de espécies espinhosas & Substituição por outras espécies \\
\hline & Falta de limpeza & Manutenção periódica de limpeza \\
\hline & Falta de área para lanches & Implantação de quiosques \\
\hline Praça 2 & Passeios estreitos (com menos de $1,20 \mathrm{~m}$ ) & Adequação para largura superior ao mínimo indicado \\
\hline
\end{tabular}

Fonte: Elaborado pelos autores.

Dentre os pontos positivos identificados na avaliação das praças, a localização é um dos aspectos a serem destacados, visto que essa conexão com o entorno promove a atração de pessoas. Além disso, foi observado que ao menos em um turno do dia, as praças apresentaram uma quantidade considerável de usuários, indicando que independente das problemáticas existentes, esses espaços ainda são procurados, seja para prática de atividade física, seja como ponto de encontro e conversa. 


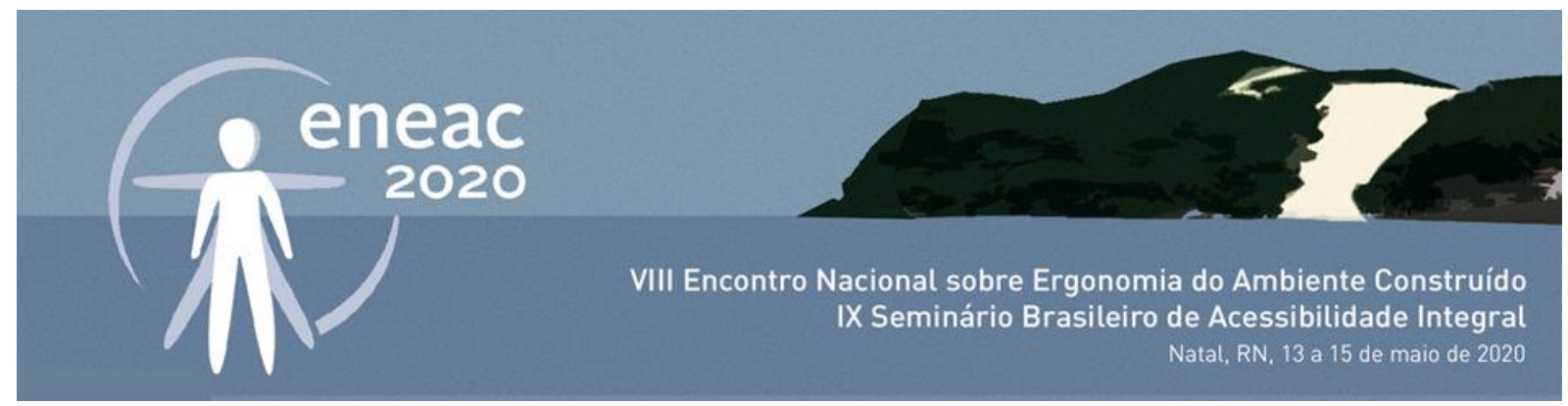

\section{CONSIDERAÇÕES FINAIS}

No desenvolvimento deste trabalho averiguou-se, com a elaboração dos mapeamentos comportamentais, que a Praça José de Barros é mais utilizada e possui maior número de usuários, no entanto, pela aplicação das ferramentas de pesquisa de opinião dos usuários, a Praça Coronel Nanan demostrou um maior índice de satisfação. Inúmeros são os fatores relacionados à preferência de uso do espaço público, entretanto, mesmo ambas as praças possuindo problemáticas, ainda assim, possuem potencialidades que devem ser aproveitadas e utilizadas como parâmetro norteador para possíveis intervenções.

O olhar da ergonomia do ambiente construído possibilitou uma ampla compreensão das praças em estudo. A conciliação entre o olhar técnico do pesquisador e a percepção dos usuários dos espaços, permitiu que fossem estabelecidas considerações pertinentes e condizentes com a área analisada. Essa identificação de problemáticas e indicação de recomendações pode ser um primeiro passo na busca pela melhoria do espaço público, e que esse seja de acesso livre e igualitário.

\section{AGRADECIMENTOS}

Por fim, finalize-se com o agradecimento à Fundação Cearense de Apoio ao Desenvolvimento Científico e Tecnológico - FUNCAP pelo apoio à realização dessa pesquisa.

\section{REFERÊNCIAS}

ASSOCIAÇÃO BRASILEIRA DE NORMAS TÉCNICAS. NBR 9.050: Acessibilidade de pessoas portadoras de deficiências e edificações, espaço, mobiliário e equipamentos urbanos. Rio de Janeiro, 2015.

ASSOCIAÇÃO BRASILEIRA DE NORMAS TÉCNICAS. NBR 10151: Acústica - Avaliação do ruído em áreas habitadas, visando o conforto da comunidade - Procedimento. Rio de Janeiro, 2000.

CABRAL, A. K. P.; FIGUEIREDO, L. S.; MONTEIRO, P. de S.; VILLAROUCO, V. Avaliação de calçadas públicas em Instituição de Ensino Superior sob a ótica da ergonomia do ambiente construído. In: Anais do VI Encontro Nacional de Ergonomia do Ambiente Construído / VII Seminário Brasileiro de Acessibilidade Integral. São Paulo: Blucher, 2012.

CEARÁ. Guia de Acessibilidade: espaços públicos e edificações. Elaboração: Nadja G.S. D. Montenegro; Zilsa M. P. Santiago; Valdemice C. de Sousa. Fortaleza: SEINFRA-CE, 2009.

FREITAS, R. M. Entre mitos e limites: as possibilidades do adensamento construtivo face à qualidade de vida no ambiente urbano. 2005. Tese (Doutorado) Programa de Pesquisa e Pós-graduação em Arquitetura da Universidade Federal do Rio Grande do Sul. Porto Alegre, 2005.

GERHARD, T. E. SILVEIRA, D. T. Métodos de pesquisa. Porto Alegre: Editora da UFRGS, 2009.

LAMAS, J.M.R.G. Morfologia urbana e desenho da cidade. Lisboa: Fundação Calouste Gulbenkian/Junta Nacional de Investigação Científica e Tecnológica, 1993

NHO, Norma de Higiene Ocupacional do Ministério. NHO-11: Avaliação dos níveis de iluminamento em ambientes internos de trabalho. São Paulo, 2018.

NR, Norma Regulamentadora Ministério do Trabalho e Emprego. NR-17: Ergonomia. 2018.

NIEMEYER, C. A. da C. Percepção e desempenho ambiental em praças públicas na cidade de Caraguatatuba - SP. 2015. Tese (Doutorado). Faculdade de engenharia civil, arquitetura e urbanismo da Universidade Estadual de Campinas. Campinas 2015.

PAIVA, M. M. B. VILLAROUCO, V. Ergonomia no ambiente construído em moradia coletiva para idosos: estudo de caso em 


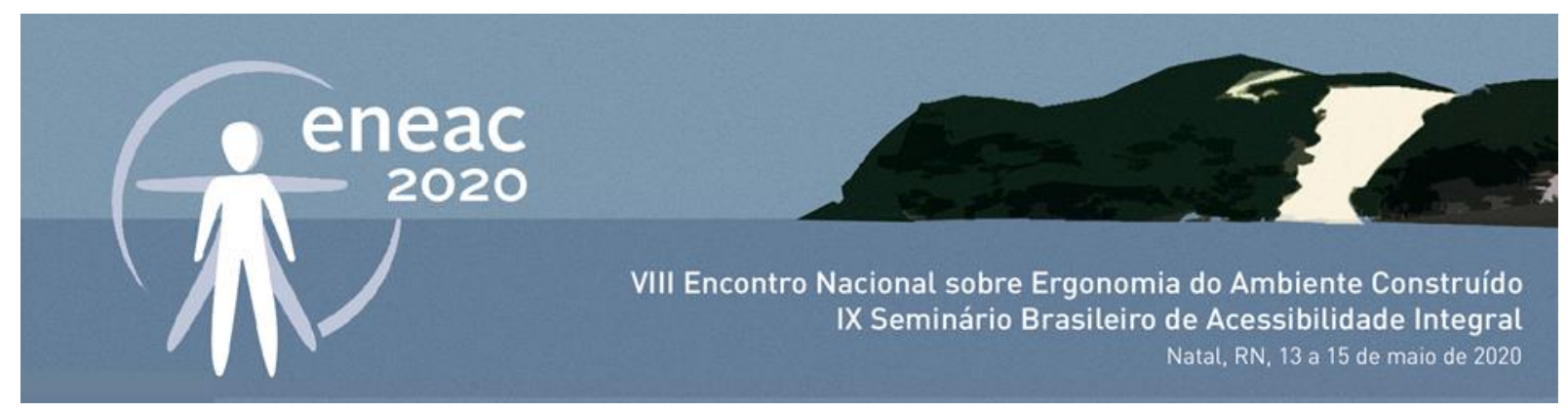

Portugal. Revista Ação Ergonômica. v. 7, n. 3 p. 56-75. 2012.

PANERO, J.; ZELNIK, M. Dimensionamento Humano para Espaços Interiores. 8a Ed. México, D.F., Gustavo Gili, 2008.

PINHEIRO, J. Q.; ELALI, G. A.; FERNANDES, O. S. Observando a interação pessoa-ambiente: vestígios ambientais e mapeamento comportamental. In: PINHEIRO, J. Q.; GÜNTHER, H. Métodos de pesquisa nos estudos pessoa ambiente. São Paulo: Casa do Psicólogo, 2008. p. 75 -104.

PINTO, C. F. M. DORNELES, V. G. O walkthrough na avaliação da acessibilidade espacial em um centro de saúde em Florianópolis. In: Anais do VII Encontro Nacional de Ergonomia do Ambiente Construído / VIII Seminário Brasileiro de Acessibilidade Integral. São Paulo: Blucher, 2018.

SANTIAGO, Z. M. P.; SANTIAGO, C. Q. de; SOARES, T. S. Acessibilidade no espaço público: o caso das praças de Fortaleza. Revista Ergodesign $\mathrm{HCl}$, [S.I.], v. 4, n. 2, p. 32-39, 2016.

VILLAROUCO, V. Construindo uma metodologia de avaliação ergonômica do ambiente. In: Anais do XV Congresso Brasileiro de Ergonomia - ABERGO, Bahia, 2008. 